\title{
ECONOMICS AND LABOUR LAW IN BRITAIN: THATCHER'S RADICAL EXPERIMENT
}

\section{K.D. EWING*}

Professor Ewing looks at the contribution of law to economic policy. In partlcular, the role of labour law in the great "radical economic experiment" which has been conducted in Britain since 1979, following the first of Prime Minister Thatcher's three general election victories is considered. First, Professor Ewing outlines the political, legal and economic conditions inherited by Prime Minister Thatcher in 1979; next, the wide-ranging labour law reforms pursued since 1979 are examined; finally, the implications and consequences of these developments are assessed.
Le Professeur Ewing examine quelle est la contribution du droit à la politique économique. Il étudie plus particulièrement le rôle du droit du travail dans la grande "expérience économique radicale" qui a été menée en Grande-Bretagne depuis 1979. après la première des trois élections générales historiques qu' a remportées le Premier ministre Thatcher. $L$ 'auteur décrit les conditions politiques, juridiques et économiques dont elle a hérité à l'époque, les vastes réformes auxquelles elle a procédé dès 1979 en matière de droit du travail, et il évalue enfin quels en sont les implications et les conséquences.

We are here today to commemorate the achievements of John Alexander Weir, the first Dean of the Faculty of Law in this University. By all accounts Dean Weir was an accomplished scholar in the fine traditions of the common law. Early volumes of the Canadian Bar Review carry articles by Dean Weir on subjects as diverse as unjust enrichment;' contributory negligence; ${ }^{2}$ and mistake in the law of contract. ${ }^{3}$ It is appropriate that these should be amongst the many issues which are the subject of study by the increasingly influential law and economics community. For we are also here today to celebrate the installation of Dr. Paul Davenport as President of the University. Dr. Davenport is, of course, a distinguished economist whose published works have crossed disciplinary frontiers to find a home in the law reviews. ${ }^{4}$ It is the contribution of law to economic policy which is the subject of my talk today. In particular I wish to consider the role of labour law in the great radical economic experiment which has been conducted in Britain since 1979 following the first of Mrs. Thatcher's three historic general election victories. I propose first to outline the political, legal and economic conditions inherited by Mrs. Thatcher in 1979; to examine the wide-ranging labour law reforms pursued since 1979; and finally to assess the implications and consequences of these developments. I should add at the outset that I am not an economist and that I seek the indulgence of those of you to whom this may become painfully obvious.

I.

According to one analyst, in 1979 Britain continued to suffer "a very low rate of economic growth [for] a highly developed, democratic nation."'s

* Professor of Public Law, King's College, University of London.

1. J. Weir, "Frustration of Adventure and Unjust Enrichment" (1929) 7 Can. Bar Rev. 419.

2. J. Weir, "Davies v. Mann and Contributory Negligence Statutes" (1931) 9 Can. Bar Rev. 470.

3. J. Weir, "Mistake in the Law of Contracts" (1941) 19 Can Bar Rev. 391.

4. P. Davenpor, "The Constitution and the Sharing of Wealth in Canada" (1982) 45 Law and Contemporary Problems 109.

5. Rowley, "Toward a Political Economy of British Labor Law" (1984) 51 U. of Ch. L. Rev. 1135 at 1150 . 
Many writers have commented on the rigid and inflexible British labour force which was grossly overmanned and unproductive when compared with workers in other countries. For some analysts much of the fault lay with the beneficial political and legal culture which not only allowed unions to retain restrictive labour practices and outdated methods, but which by the use of the strike weapon also enabled unions to bargain for wage levels commensurate with their more productive competitors. ${ }^{6}$ But whatever conclusions can be drawn from the productivity of the British worker, there is no escape from the overall conclusion that the economic outlook in 1979 was very grim. Unemployment stood at $1,305,700$ workers, representing 5.5 per cent of the labour force. This compared with half a million in 1974, representing only 2.4 per cent of the labour force. And if unemployment was a cause for concern, so too was inflation. It is true that the Labour government administration had inherited an inflation rate of 13.2 per cent in 1974. But this was to rise to a staggering 22.9 per cent in 1976 , falling to 9.5 per cent in 1978, rising again to 19.1 per cent by 1980 . Although this could be explained partly by the rise in oil prices, other indicators of economic performance were just as bleak. The balance of payments showed a deficit in all but one of the years between 1974 and 1979 and our share of total world exports continued its steady decline from 11.6 per cent in 1948 to 5.5 per cent in 1978. Countries such as West Germany, Italy, France and the Netherlands in contrast saw their share of the world market steadily increase.

Following its election the Conservative government sought to tackle the underlying problems of the economy of which these negative indicators were a depressing symptom. This was done in several ways, involving the implementation of revolutionary new economic and labour-market policies. The new economic policy involved a rejection of the post-war consensus that the primary goal of government was the control of unemployment. In its place "faith was put in so-called monetarism, which essentially [put] the pursuit of price stability at the heart of macro-economic policy." 7 Unemployment levels would depend primarily on employers, workers and consumers with the role of government being confined to creating a climate in which enterprise could flourish by removing obstacles to the efficient working of the labour market. ${ }^{8}$ Trade unions represented one such obstacle, with the influential Nobel Prize-winning economist F.A. Hayek writing that trade unions and collective bargaining raise labour costs beyond their true market level which in turn creates unemployment. ${ }^{9}$ For as Posner has written in expressing similar views, high labour costs amongst unionised workers impacts negatively on "workers who cannot

6. This is a view which was endorsed by the Thatcher government. See Department of Employment, Employment: The Challenge for the Nation (Cmnd: 9474) (H.M.S.O., 1985).

7. Standing, Unemployment and Labour Market Flexibility: The United Kingdon. (I.L.O., 1986) at 41 .

8. Employment: The Challenge for the Nation, supra, note 6. For an important critique of British economic policy in general and labour market policy in particular, see Deakin and Wilkinson, Labour Law, Social Security and Economic Inequality (Institute of Employment Rights, 1989). See also Wilkinson, "Government Policy and the Restructuring of Labour Markets: the Case of the United Kingdon" [mimeo] (1988).

9. Hayek, 1980s Unemployment and the Unions (second edition) (Institute of Economic Affairs, 1984). The influence of Hayek is noted also in Wedderbum of Charton, "Freedom of Association and Philosophies of Labour Law" (1989) 18 Industrial Law Joumal 1. 
find employment because of the reduction in the demand for labour caused by union wage scales." 10 And apart from increasing labour costs, trade unionism was thought by the government to be responsible for rigidity and the lack of labour flexibility. Trade union resistance hinders managerial needs to adapt quickly to new products and processes. This led to lack of competitiveness and in turn was further responsible for unemployment.

But trade unionism and collective bargaining are not the only obstacles to labour market efficiency which have attracted government attention. Increasingly a second concern has been the whole package of employment standards legislation which has been gradually built up since the 19th century to offer minimum rates of pay, a safe and healthy working environment, and security of employment in the sense of protection from arbitrary discharge. Whatever the merits of this legislation, the government was concerned that the total effect when imposed across the whole of industry is often to deter employers especially small ones - from taking on workers." The careful pursuit of statutory (or externally) guaranteed protection against disadvantage for every individual circumstance can thus yield for many people, the severest disadvantage of all - the lack of a job. ${ }^{12}$ These views find an echo in the writing of Posner $^{13}$ and others ${ }^{14}$ where we also find an attack on minimum wage laws, occupational health and safety legislation as well as attempts to modify the harsh effects of employment at will - a pernicious doctrine which happily seems confined to the United States. ${ }^{\text {is }}$ But not only is this legislation calculated to discourage employment generally, according to the Thatcher government it is also calculated to discourage the creation of particular kinds of jobs. Although it is not clear why, the disincentive impact of employment standards legislation is particularly true of legislation intended to protect part-time employees. So comprehensive coverage means that there are fewer part-time jobs than there might otherwise be, which it is claimed puts women at a particular disadvantage for whom flexible part time work is particularly attractive. ${ }^{16}$ In other words, it is economically desirable to treat women less favourably than men for to do so will lead to more employment of women.

II.

If we look first at the measures designed to reduce the influence of trade unions in the functioning of the labour market, the radical nature of the government's program will become very readily apparent. Three examples may serve to illustrate the new policy in this area. The first is the question of trade union recognition, supported by an I.L.O. Convention which provides that "Meas-

10. Posner, Economic Analysis of Law 3rd ed. (Little, Brown, 1986).

11. See Employment: The Challenge for the Nation, supra, note 6.

12. Ibid. See also Department of Employment, Building Businesses . . . Not Barriers. (Cmnd: 9794) (H.M.S.O., 1985).

13. See Posner, supra, note 10 at c.11.

14. Epstein, "In Defense of the Contract at Will" (1984) 51 U. of Ch. L. Rev. 947.

15. There is unfortunately some evidence that the courts are beginning to retrace earlier steps to modify this doctrine. See New York Times, 30 December 1988, on major recent developments in Califomia.

16. See Building Business . . Not Barriers, supra, note 12. 
ures appropriate to national conditions shall be taken, where necessary, to encourage and promote the full development and utilisation of machinery . . . with a view to the regulation of terms and conditions of employment by means of collective agreements. "I7 In Alberta this is implemented by the certification procedure in the Labour Relations Act and in Britain the Convention was implemented in a number of ways, most recently by the Employment Protection Act 1975 which contained a rough, if much less legalistic, equivalent to the Canadian certification procedure. ${ }^{18}$ It is perhaps a measure of the government's hostility to trade unions that there is not now any legal machinery in Britain to encourage or facilitate collective bargaining at the workplace. The recognition legislation was repealed in $1980^{19}$ - as one of the first steps of the government - and other forms of state support for trade union recognition and collective bargaining have been withdrawn or prohibited. So while public corporations were under a statutory duty to negotiate with representative trade unions those obligations have not been transmitted to the growing number of privatised services. On the contrary an indication of the new approach is the legislation of 1982 which prohibits local government authorities from using their power of contract to require contractors to recognise and negotiate with trade unions. ${ }^{20}$

The second example relates to union security arrangements. Typically in Canadian jurisdictions a certified bargaining agent and an employer may enter into a union shop agreement whereby employees in the unit must join the union or pay what the Americans would call an agency fee to the union for the services which the union provides. Indeed in some jurisdictions such as Ontario the certified union may insist on such an arrangement and negotiate for an even stronger security device. ${ }^{21}$ In Britain, too, union security arrangements were accepted in the sense that a trade union and an employer were free to enter into a voluntary agreement whereby designated employees would be required to be members of designated trade unions on pain of dismissal. ${ }^{22}$ The only exception provided by the law was for those employees who had genuine religious objections to trade union membership, though in practice these agreements were generally much more generous. ${ }^{23}$ Yet although employees were not compelled to enter into such agreements, they were quite widespread in Britain with one authoritative study showing that as much as 23 per cent of the labour force ${ }^{24}$ was employed in situations where union membership was compulsory. These high levels reflected the reality, acknowledged by the present government in 1979, that although closed shop agreements limit individual

17. International Labour Conference, Convention concerning the Application of the Principles of the Right to Organise and to Bargain Collectively (Convention No. 98), Article 4.

18. Dickens, “ACAS and the Union Recognition Procedure" (1978) 7 Industrial Law Joumal 160.

19. Employment Act 1980, s. 19(b).

20. Employment ACt 1982, ss 12 and 13. The govemment also revoked the Fair Wages Resolution 1946 which required government contractors to respect the right of their employees to join trade unions.

21. Labour Relations Act, R.S.O. 1980, ss. 43, 36.

22. Employment Protection (Consolidation) Act, 1978, s. 58.

23. Benedictus, "Closed Shop Exemptions and their Wording" (1979) 8 Industrial Law Joumal 160.

24. Dunn and Gennard, The Closed Shop in British Industry (Macmillan, 1984). 
freedom, employers and unions have long and practical reasons for entering into such agreements. ${ }^{25}$ It is perhaps relevant to note that these utilitarian arguments were accepted by the Ontario courts which at least at first instance held that although union security arrangements compromise the Canadian Charter of Rights and Freedoms protected right to freedom of association, the violation could nevertheless be justified under section $1 .{ }^{26}$

But for the new regime in Britain, union security arrangements are completely unacceptable, and Parliament has readily intervened to accept the challenge declined by the Lavigne court in Ontario. ${ }^{27}$ Union security arrangements are unacceptable not only on civil libertarian grounds, but also on economic grounds. According to Hayek, the closed shop reinforces trade union strength in the marketplace by providing them with coercive powers over workers. ${ }^{28}$ It is, in other words, an institution which enhances the discipline and efficiency of the union in collective bargaining by raising the costs of dissent by members to unacceptably high levels. This is reinforced by evidence which is claimed to show that "labour costs are higher in plants where unions bargain over the pay of manual workers, even taking account of a large number of other factors. The range of the union mark up is wide, and one important element in explaining the variations is the presence of or absence of a closed shop." 29 Given the concern to reduce obstacles to the proper functioning of the market it was inevitable that the union security arrangement would be a target for detailed and sustained scrutiny. And so it has been with the rhetoric of civil libertarianism as the justification for the policy barely disguising a more fundamental economic concern which was rarely publicly acknowledged. Early attacks on the closed shop effectively killed it by introducing compulsory ballots requiring 80 per cent or 85 per cent support, by introducing wide conscience clauses, and by excluding from the obligation to join the union any worker on the payroll at the time the agreement was introduced. ${ }^{30}$ The government has since taken the logical step of giving legal effect to practical reality by making it unlawful

25. Department of Employment, Working Paper for Consultations on Proposed Industrial Relations Legislation. The Closed Shop. [mimeo] (1979).

26. See especially Lavigne v. Ontario Public Service Employees Union (1986) 26 D.L.R. (4th) 200. For analysis, see K. Ewing, "Freedom of Association in Canada" (1987) XXV Alta L. Rev. 437; also see Etherington, "Freedom of Association and Compulsory Union Dues: Towards a Purposive Conception of a Freedom to Not Associate" (1987) 19 Ottawa L.R. I.

27. It is true that by virtue of a decision of the European Court of Human Rights the British government would have been compelled to "liberalize" the law anyway. The Court held that British law violated the freedom of association guarantees in the Convention (Article 11). However, the decision of the Court did not require the government to go nearly as far as it did. See Young, James and Webster v. U.K. [1981] I.R.L.R. 408. See Forde, "The Closed Shop Case" (1981) 10 Industrial Law Journal 1.

28. Hayek, The Constitution of Liberty (Routledge \& Kegan Paul, 1960).

29. Department of Employment, Removing Barriers to Employment. Proposals for the Further Reform of Industrial Relations and Trade Union Law (Cm 655, 1989) at 5.

30. Though surprisingly it was not completely killed off. In 1985 , the Advisory Conciliation and Arbitration Service reported that it had heard of 107 union membership agreement ballots since the inception of the provisions, 90 per cent of these in engineering. Four-fifths had led to a vote for continuation. See Advisory Conciliation and Arbitration Service, 1985 Annual Reporn (1986) at 17. For the early law, see Elias, "Closing in on the Closed Shop" (1980) 9 Industrial Law Joumal 201; and Lewis and Simpson, "Disorganising Industrial Relations: An Analysis of sections 2-8 and 10-14 of the Employment Act 1982" (1982) 11 Industrial Law Joumal 227. 
for an employer to dismiss someone for non-membership of a trade union..$^{31}$ In some cases judgment can be executed by the dismissed worker against the union.

The third example of the new trade union policy relates to the right to strike. Given the fact recognised by the MacDonald Commission that "The right to strike . . . is heavily regulated in Canada as compared to other countries," 32 the radical nature and the scale of what has been done in Britain can only be fully appreciated by recalling that there has been traditionally little legal regulation of industrial conflict with the state's preferred option being the voluntary conciliation of disputes. It is true that the wide immunities from legal liability which sustained this system attracted expressions of outrage from Hayek and others on the ground that such special privileges violated the rule of law, ${ }^{33}$ quite apart from their damaging economic consequences. Nevertheless, it was accepted, even in the House of Lords, that "the right of workmen [sic] to strike is an essential element in the principle of collective bargaining." "But in the new era there is no commitment to collective bargaining and no need to protect the right to strike as its logical corollary. On the contrary the concern is to weaken the ability of unions to push for higher wages or to resist the introduction of changes at the workplace. So just as the government has attempted to reduce the coercive power of unions over employees, so it has legislated to reduce the coercive power of unions over employers. This has been done, not by declaring strikes unlawful, but by restoring some of the common law powers of employers first by making it easier to the employer lawfully to dismiss striking workers, ${ }^{35}$ at a time when the provincial government here in Alberta has increased the protection for strikers. ${ }^{36}$ But secondly, the government has also restored the employers' power over unions by withdrawing the tortious immunities from some forms of industrial action which the unions have historically enjoyed.

So far as restoring tortious liability is concerned, the government's approach so far has not been the total withdrawal of the immunities, though there are those of the "New Right"' who see this as the ultimate solution. ${ }^{37}$ Rather, the government has imposed a number of restrictions, one of which is a requirement that strike action must be supported by a secret ballot of the workers who

31. McKendrick, 'The Rights of Trade Union Members - Part 1 of the Employment Act 1988'" (1988) 17 Industrial Law Joumal 141.

32. Royal Commission on the Economic Union and Development Prospects for Canada. Report, Volume II, (Ministry of Supply and Services Canada, 1985) at 70I.

33. Hayek, The Constitution of Liberty, supra, note 28. See also Hanson, “From Taff Vale to Tebbit. A Postscript on British Trade Unions and the Law" in Hayek, 1980s Unemployment and the Unions, supra, note 9.

34. Crofier Hand Woven Harris Tweed v. Veitch, [1942] A.C. 435, at p. 463 per Lord Wright. See also Collymore v. Altorney General for Trinidad and Tobago. [1970] A.C. 538.

35. Employmet Act 1982, s. 9. See Wallington, "The Employment Act: Section 9 - A Recipe for Victimisation?" (1983) 46 Mod. L.R. 310.

36. Labour Relations Act, S.A., c.L-1.2, s. 88.

37. Hanson and Mather, Striking out Strikes (Institute of Economic Affairs, 1988). See also Hanson and Mather, "Submission to the Department of Employment in Response to the Green Paper Removing Barriers to Employment" [mimeo] (1989). 
are called upon to support it. ${ }^{38}$ This is a measure which was designed to stop strikes, on the assumption that workers were being called out against their will. Failure to ballot restores tortious liability to the employer, but also allows members of the union to sue supported in this instance by a specially-created public official, the Commissioner for the Rights of Trade Union Members (mischievously referred to as CROTUM) $\cdot{ }^{39} \mathrm{~A}$ second initiative by the government which may be mentioned here are the restrictions on the tactics which may be used to promote a dispute which is supported by a ballot. Limitations on the power to impose secondary boycotts ${ }^{40}$ are about to be extended to make all such action outside the scope of immunity, ${ }^{41}$ while all forms of secondary picketing have been unprotected from the common law since $1980 .{ }^{42}$ Workers may now only picket outside their own place of work and by virtue of a Code of Practice issued with statutory authority workers who do confine their picketing to their place of work may do so only if the number of pickets does not exceed six. Industrial action outside the scope of these narrowed immunities may be restrained by injunction at the suit of the employer who may also proceed against the union for damages. And unions have recently paid a high price for ignoring injunctions, with heavy contempt fines being imposed followed by the sequestration of all assets until the contempts are discontinued and purged. ${ }^{43}$

III.

If we turn now to examine the measures designed to remove the rod of employment standards legislation from the backs of employers, we may again highlight the direction of the government's program and the radical nature of its policies. ${ }^{44}$ Very little of the statutory framework inherited in 1979 has been left untouched, whether by direct legislative intervention or indirectly by administrative neglect by failing properly to fund the enforcement agencies. Indeed, in order to promote this radical revision the government has thought it necessary to renounce a number of I.L.O. Conventions ratified by earlier British administrations. ${ }^{45}$ From this comprehensive review of the legislation, again three examples may serve to illustrate the new policy in this area. The first is the initiatives introduced to relieve small businesses, ${ }^{46}$ alleged to have

38. Trade Union Act 1984, ss. 10, 11. See Hutton, "Solving the Strike Problem: Part II of the Trade Union Act 1984" (1984) 13 Industrial Law Joumal 212.

39. Both the member's right to sue and the CROTUM were introduced by the Employment Act 1988. See McKendrick, supra, note 31.

40. Employment Act 1980, s. 17.

41. Department of Employment, Removing Barriers to Employment, supra, note 29.

42. Department of Employment, Code of Practice: Picketing (H.M.S.O., 1980).

43. Wedderbum of Charlton, "The Injunction and the Sovereignty of Parliament" (1989) 23 Law Teacher 4.

44. For fuller analysis, see Deakin, "Labour Law and the Developing Employment Relationship in the U.K." (1986) 10 Cambridge Joumal of Economics 225.

45. On the denunciation of I.L.O. Conventions, see Widdows, "The Denunciation of International Labour Conventions" (1984) 33 International and Comparative Law Quarterly 1052.

46. On the small firm question, see Smith, "Employment Laws and the Small Firm" (1985) 14 Industrial Law Joumal 18. 
the most difficulty with this legislation and which as a result are allegedly most reluctant to hire labour. So in 1980 it was provided that a small business need not take back a woman who has qualified for statutory maternity leave. ${ }^{47}$ In the same year, measures were introduced to dilute the application of the unfair dismissal regime to small businesses. For example, those responsible for adjudicating claims were to have regard to the size and administrative resources of an employer in determining the faimess of a dismissal. ${ }^{48}$ And more recently, proposals currently contained in the Employment Bill 1989 now before Parliament will relieve small businesses from some of the obligations to provide contractual information to employees. ${ }^{49}$

The second example is of general application and is not confined to small businesses. This relates to the regulation and protection of wages. Statutory minimum wages have attracted considerable hostility in both Britain and the United States by many who regard them as counter-productive. These sentiments are well expressed by a passage in the MacDonald Commission's report where it is argued that "The fundamental difficulty with using a minimum wage as a tool to reduce poverty is that increases in that figure can be expected to reduce employment opportunities for low wage earners. " 50 Higher minimum wage levels it is said will induce some employers to insist on labour saving alternatives and will make higher paid more productive workers less unattractive. In contrast to the different Canadian jurisdictions, Britain has never had a statutory minimum wage of general application. There is however, a functional equivalent in the form of wages councils, which began life on a very small scale in 1909. ${ }^{51}$ Modelled closely on legislation in Victoria, Australia, the trade boards (as the councils were called until 1945) were originally conceived as a means of combating the problems of 'sweated labour' ${ }^{52}$ Under subsequent legislation (of 1918, 1945, 1975 and 1979) the system expanded with wages councils being used to settle wages and other terms and conditions of employment in areas where collective bargaining arrangements were limited. Indeed one of the functions of these state created tripartite bodies was that they should eventually lead to the development of mature collective bargaining arrangements from which the state could retreat. In practice, however, this aspiration was rarely fulfilled.

There are today some 26 wages councils covering 2.75 million workers primarily in service industries such as retailing, catering and hairdressing. In 1985 , the minimum rates of pay set by wages councils were between $f 63$ and $£ 72$ per week, which was lower than the statutory minimum wage paid in Alberta. Yet for similar reasons expressed by the MacDonald Commission, the Thatcher government canvassed the possibility of abolishing the wages councils, a rather extreme measure which would have left many vulnerable workers very exposed. As if to facilitate this step, the administration renounced I.L.O.

47. Employment Act 1980, ss. 11-12.

48. Employment Act 1980, s. 6.

49. Employment Bill 1989, clause 9.

50. Royal Commission on the Economic Union and Development Prospects for Canada; supra, note 32 at $619-620$.

51. Trade Boards Act 1909.

52. K. Ewing, "Homeworking: A Framework for Reform" (1982) 11 Industrial Law Journal 94 at 98. 
Convention No. 26 which requires countries to create or maintain minimum wage fixing machinery. In the new free labour market, wages councils interfere with the freedom of employers to offer and job-seekers to accept, jobs at wages that would otherwise be acceptable. This in turn led to claims that "slower rises in real pay would lead to significant increases in job opportunities", while "Deregulation is desirable in principle." 53 In the meantime, however, the government has stopped short of a complete abolition, though as the MacDonald Commission indicated (by proposing that "Canadian governments should be careful in the future not to allow minimum wages to rise too quickly" 54 ) statutory wage-fixing machinery can be largely eviscerated by stopping short of repeal. In Britain substantial steps in this direction were taken first by reducing the powers of the councils so that they may only regulate wages but not also other terms and conditions of employment; secondly by excluding young workers from their coverage thereby placing a premium on replacing established protected staff with unprotected youths; $;{ }^{55}$ and thirdly by reducing the number of wages inspectors by administrative means by 35 per cent since $1979,{ }^{56}$ despite the fact that (according to government figures) between 35 and 42 per cent of establishments visited by inspectors were underpaying their staff. ${ }^{57}$

The thind example of the new policy on employment standards is perhaps even more controversial than the assault on minimum wage levels. This is the attention which the government has directed towards job security legislation. Unlike in Canada, even trade union members covered by a collective agreement would not normally look to that agreement for a remedy in the event of dismissal. There are in Britain no "just cause" clauses, no grievance arbitration, and no problem with fair representation. In contrast, we have chosen to implement the I.L.O. Recommendation of 1963 in common with most European states by providing a statutory right not to be unfairly dismissed for all workers who satisfy eligibility requirements which do not depend on whether they are trade union members or whether they are covered by a collective agreement. An eligible worker who has been dismissed and who claims that the dismissal is unfair may complain to an industrial tribunal, a relatively informal localised labour court which is part of the judicial arm of the state. ${ }^{58}$ This tribunal is a tripartite body before which parties often appear without the benefit of legal representation, with the tribunal being empowered to recommend the reinstatement or the payment of an award of compensation to a worker found to have been unfairly dismissed. Given the wide and comprehensive nature of this protection it is perhaps not surprising that it should have been so widely condemned as presenting a major obstacle to labour market efficiency.

53. Department of Employment, Consultative Paper on Wages Councils (1985).

54. Royal Commission on the Economic Union and Development Prospects for Canada, supra, note 32 at 622.

55. Wages Act 1986.

56. Wedderburn of Charlton, "Freedom of Association and Philosophies of Labour Law", supra, note 9.

57. Department of Employment, Consultative Paper on Wages Councils, supra, note 53.

58. Employment Protection (Consolidation) Act 1978, s. 54. A full chapter of most labour law textbooks is devoted to the exposition of this matter. 
Although there is no empirical evidence to support this view the idea persisted in some quarters and in government that more than any other single legal measure, the legislation on unfair dismissal was a disincentive to employment because it was too difficult and expensive to dispense with the services of the inefficient or those no longer needed.

In addressing these concerns, the government has stopped some way short of abolishing the right not to be unfairly dismissed, though again there are those of the "New Right" who would see this as the ultimate solution. To some extent, it is true, the government has been relieved of the obligation to act because of the growing "casualization" of the labour force and the growth of atypical forms of employment. ${ }^{59}$ Many of these new workers do not qualify for unfair dismissal because they are not regarded as working under a contract of service even though their dependence on their employer is complete. ${ }^{60}$ This, of course, has not been enough, and the government has moved incrementally to impose a number of statutory restrictions on the scope of the legislation. The most significant so far has been the introduction of a new qualifying condition for the bringing of complaints. In 1979 a worker could sue for unfair dismissal if he or she had been employed by the dismissing employer for six months. This was extended to one year and subsequently to two years. Employees engaged for less than two years have no legal protection against dismissal, and save only for their right to a week's notice ${ }^{61}$ are in a position not unlike the euphemistically called "Free Enterprise Personnel" who are employed-at-will in the United States. ${ }^{62}$ Steps have also been taken to make it more difficult for workers who do qualify to succeed with their complaints and to discourage them from bringing complaints in the first place. A particularly controversial proposal is contained in the Employment Bill 1989 currently before Parliament, having been first proposed in a 1985 White Paper discussing possible means of removing burdens from business. ${ }^{63}$ This is the proposal, quite unprecedented in British tribunal adjudication, that in some cases dismissed workers will be required to make a payment (of up to $£ 150$ ) to the tribunal as a condition of proceeding further with the complaint. ${ }^{64}$

\section{IV.}

What then have been the implications of the government's use of labour law as an instrument of labour market policy? The purpose has been clearly to do what Professor Epstein proposed in the Yale Law Journal, ${ }^{65}$ namely to restore

59. See Deakin, "Labour Law and the Developing Employment Relationship in the U.K." supra, note 44.

60. For a leading example of this, see $O$ 'Kelly v. Trusthouse Forte, [1983] I.C.R. 728.

61. Employment Protection (Consolidation) Act 1978, s. 49.

62. See Johnson v. McDonnell Douglas Corporation, 2 I.E.R. Cases 1799 (1988) (Missouri Supreme Court).

63. Department of Employment, Building Businesses . . . Not Barriers, supra, note 12. The proposal met with fierce criticism and appeared to have been dropped.

64. Employment Bill 1989, clause 16.

65. Epstein, “A Common Law for Labor Relations: A Critique of the New Deal Labor Legislation" (1983) 92 Yale Law Joumal 1357. 
the common law to the field of labour relations by removing the immunities and privileges which legislation has extended to workers and their organisations - an analysis which incidentally could be applied in the Canadian setting as in the British. ${ }^{66}$ Restoring the common law, however, does not mean creating a regime of legal neutrality in the workplace. Rather, it means restoring legal rules fashioned in the nineteenth century giving absolute power to the employer. Yet despite this radical rhetoric, in reality the government has not had the courage of its convictions. The restoration of a common law regime has been only partial. For despite these changes minimum wage laws remain in force; most workers continue to enjoy statutory protection from unfair dismissal; and the traditional strike over pay or in resistance to imposed terms remains protected from liability in tort. Paradoxically indeed the contract of employment is becoming an irritant for employers, with the courts beginning to fashion effective remedies to resist the unilateral imposition of new terms and conditions and to prevent dismissals on grounds not authorised by the contract. ${ }^{67}$ It is thus perhaps not surprising that there should be despair amongst some of the new supply-side economists, two of whom have written recently that the government's labour law policy to date has been "over-cautious when compared with the state of Britain's labour market." ${ }_{68}$ The need, it seems, is for a full blown common law of the enterprise.

Whatever the merits of this position - described by one leading Canadian labour lawyer as "nonsense" ment to go any further down this road. In the first place the government appears to have exhausted the political capital in what was initially a very popular program. Even the influential Economist magazine has been forced to concede that "Going further could be to sail close to the invisible line where the loss of individual freedom outweighs the good for the economy and society." 70 Indeed the restrictions on economic and social rights has already brought the government into conflict with legal obligations, a conflict which is calculated to become even sharper and even more embarrassing. It is true that there is nothing equivalent to the Charter of Rights and Freedoms in British law; however, following the decision in the Alberta Reference case ${ }^{71}$ and the decision of the Privy Council ${ }^{2}$ on which the Supreme Court of Canada to some extent relied, it appears doubtful whether a document such as the Charter could be successfully employed in this area to protect the labour law regime from being decon-

66. Epstein, ibid., refers to the Wagner $A c t$ as conferring immunities on American labor.

67. Though it has to be said that these developments (on which see Carty. "Dismissed Employees: The Search for a More Effective Range of Remedies" (1989) 52 Mod. L.R. 449) are taking place at the same time as other courts have enhanced the employer's power by implying into the contracts of employment a duty of flexibility on the part of employees. See Cresswell v. Inland Revenue [1983] I.R.L.R. 190.

68. Hanson and Mather. "Submission to Department of Employment in Response to the Green Paper 'Removing Barriers to Employment" ", supra, note 37.

69. Adell, "Perspectives of Power and Perspectives of Principle in Canadian Labour Law Scholarship", in McKenna, ed., Labour Relations into the 1990s (CCH Canadian, 1989), at 30.

70. "Strike and Counter-Strike". The Economist, 1 July 1989.

71. Reference re Public Service Employee Relations Act, Labour Relations Act and Police Officers ' Collective Bargaining Act (1987), 38 D.L.R. (4th) 161.

72. Collymore v. Attorney General of Trinidad and Tobago. [1970] A.C. 538. 
structed and deregulated. The breakdown of political consensus and the social disintegration flowing from it perhaps provide a vivid indication of the inadequacy and danger inherent in the Supreme Court of Canada's policy of judicial deference to the legislative branch which inexplicably seems confined to the industrial relations sphere. ${ }^{73}$ There are, however, obligations under international law which seek to guarantee economic and social rights regardless of what national constitutions and legislation may fail to provide. The British government's flirtation with new supply-side economics has brought condemnation from the international legal community reinforcing the view obvious from the text of international treaties that this type of policy, or at least this manner of implementation, is simply not compatible with the legal and political obligations of a modem western democracy.

The I.L.O. in particular has had a number of occasions to criticize the British government for multiple violations of Convention 87 on Freedom of Association and the Right to Organise and Convention 98 on the Right to Organise and Bargain Collectively. ${ }^{74}$ This condemnation has, however, been ignored by the government, as indeed has the criticism of the Council of Europe which has drawn attention to violations of the European Social Charter..$^{75}$ But although such violations are embarrassing, neither the I.L.O. nor the Council of Europe has adequate enforcement machinery to ensure that these violations will be remedied. Much more important then and much more dangerous for the government are the European Communities, and in particular the European Economic Community (E.E.C.), where the legislative and judicial rulings must be implemented by member states. A crucial feature of the Treaty of Rome setting up the E.E.C. was that, although intended to create an economic common market (which will be fully implemented in 1992), it also gave Community institutions the authority to regulate industrial relations and deal with workers' rights. ${ }^{76}$ So as a result of E.E.C. initiatives the British government has been unable to deconstruct as much as it might otherwise wish (an example being the employers' duty to consult recognised unions about proposed redundancies) and it has also been required to deviate from its anti-worker animus from time to time, for example by introducing legislation on pay equity ${ }^{77}$ and the protection of workers in the event of a business transfer or take-over. ${ }^{78}$ But much more controversial are current French proposals (which enjoy widespread support outside Britain) for the implementation of an E.E.C. Social Charter which will require the government to roll back its restrictive statutes and legislate for employees rather than employers.

The government has attracted this international condemnation as a result of policies which are at best equivocal in terms of their impact and intended

73. For a full analysis of the right to strike trilogy, see T.J. Christian, "The Charter of Rights and Labour Law", in McKenna, ed., Labour Relations into the 1990s (CCH Canadian, 1989).

74. For an account of the now rather full concerns of the I.L.O., see Ewing, Britain and the I.L.O. (Institute of Employment Rights, 1989).

75. Herein particular because of the failure to guarantee the reinstatement of strikers, said to be in breach of Article 6(4) of the European Social Charter.

76. Treaty of Rome, Articles 117-119.

77. The Equal Pay (Amendment) Regulations 1983 (S.I. 1983 No. 1794).

78. The Transfer of Undertakings (Protection of Employment) Regulations 1981 (S.I. 1981 No. 1794). 
contribution to economic performance. Take for example the crucial question of trade union density. In 1979, 13.2 million employees were members of the trade unions, this representing 57.5 per cent of the labour force. Given the high levels of unemployment (particularly in industries where trade unionism traditionally has been strong) and given the withdrawal of legal support (by the removal of devices such as recognition and trade union security measures), it might be expected that there would be a dramatic decline in trade unionism. Yet although the number of trade unionists has fallen so that in 1987 there were 10.4 million workers in trade unions, this represented a remarkable 49 per cent of the labour force, higher in terms of numbers and a higher density than in the 1960 s, a period of growth.$^{79}$ This is not to deny that trade unionism is facing problems, some of them serious. But these have not been significantly contributed to by the legal developments. ${ }^{80}$ Although the withdrawal of support for collective bargaining may seem far reaching, it is much less significant in Britain than in Canada where in the words of one commentator, Canadians "have come to prefer legally prescribed structures and procedures over those created by employers and unions for themselves. "81 In Britain, by contrast, sophisticated collective bargaining arrangements developed without legal intervention and before the enactment of statutory procedures. These arrangements have survived the repeal of that legislation which was in any event not only of little significance for unions with established arrangements but also largely ineffective with the result that its absence has not been greatly lamented. By the same token the demise of the union shops is likely to have had only a marginal impact on the levels of union density, with its effect in practice having been to "top-up" by "compulsory" means levels of membership which were already high.

When given the choice, it seems that people choose trade unions rather than a "state of nature" or anything close to it. If trade unions are to be removed from the market place it will not be done by a policy of legal ostracism. And just as the legal support for trade unions and collective bargaining has been at best equivocal, so too have the legal restrictions on industrial action. We should not exaggerate the changes facilitating the employers' power of dismissal; this has always been a feature of British law and the notorious example of this the dismissal of 5,000 workers by Times Newspapers in $1985^{82}$ - would have been possible under the law inherited from the last Labour government. It is true that the restoration of tortious liability has had some effect, with some strike ballots being lost by unions and with some employers showing a greater propen-

79. For trade union density in the 1960s, see Clegg. The Changing System of Industrial Relations in Great Britain (Basil Blackwell, 1979) at 177-182. Trade union density did not rise above 50 per cent until 1976. In 1968 the figure was 43 per cent.

80. There is indeed a view that the Wagner model for certification and recognition of trade unions may paradoxically serve to discourage trade unionism rather than promote its growth as was intended. See Weiler, "Promises to Keep: Securing Workers Rights to Self Organization under the N.L.R.A." (1985) 96 Harvard Law Review 1769. And see the problems encountered in Canada, as discussed in The Edmonton Journal, 22 May 1988, referring particularly to the Mariposa case.

81. Forrest, "Bargaining structure, bargaining power, and the Law: a comment on the Burns Meats Case" (1989) 18 Manitoba L.J. 261.

82. Ewing and Napier, "The Wapping Dispute and Labour Law" (1986) Cambridge L.J. 285. 
sity to use the law. ${ }^{83}$ Yet as already pointed out unions still enjoy immunity in disputes on core industrial relations questions (a point vividly reflected by the recent dispute in the ports where the employers were left scrambling around, ultimately unsuccessfully, in an attempt to invest a new tort unprotected by the immunities in order to secure an injunction).${ }^{84} \mathrm{It}$ is true that the duty to hold a strike ballot may have reduced union militancy, but this is offset by the fact that there is no duty to ballot in the wildcat strikes which have made a comeback (such as that in the London Underground in 1989); and by the fact that in those cases where a strike ballot is successful (and these are the majority),$^{85}$ the vote gives strength and legitimacy to the union's position. Balloted strikes are difficult to condemn and difficult for employers to resist: they are strikes not by unions but by individual workers. Little wonder then that authors on the New Right write of the law having "backfired" in their demands for tougher restrictions. ${ }^{86}$

So trade unions continue to be relatively strong performers and refuse completely to respond to the labour market strategy as it was predicted they would. It is also significant that the economy has not responded as promised. In the first place wages in manufacturing are continuing to rise and are now outstripping production. It is true that there have been major improvements in labour productivity since 1980, but commentators are divided as to whether these gains are enduring, but all are unanimous in their conclusion that labour law reform has made no or little contribution to the development. ${ }^{87}$ Secondly, there is little cause to be sanguine about the government's claim that the unemployment levels are responding to its labour market strategy. In 1988 there were more unemployed people in Britain than live in the whole of Alberta, with 2,294,500 representing 8.1 per cent of the labour force. Fewer people were in employment in 1987 than in 1979 and although employment has been rising steadily

83. Evans, "The Use of Injunctions in Industrial Disputes: May 1984-April 1987" (1987) 25 British Joumal of Industrial Relations 419 . The author points out, however, that "even where an injunction may be available, most employers continue to prefer to resort, in the first instance at least, to customary economic and social sanctions" (p. 424) and that the willingness to use the law is concentrated heavily in three sectors, printing, public services and shipping.

84. Associated British Ports v. Transport and General Workers Union, [1989] I.R.L.R. 399. The development of new torts unprotected by the immunities was a feature of British labour law in the 1960's. For an account of some of these developments, see Elias and Ewing, "The Economic Torts and Labour Law: Old Principles and New Liabilities"' (1982) Cambridge L.J. 312.

85. See Advisory, Conciliation and Abitration Service, 1986 Annual Report (1987), at 13.

86. See Hanson and Mather, "Submission to the Department of Employment", supra, note 37.

87. See Nickell, Wadwani, and Wall, "Unions and Productivity Growth in Britain, 1974-86: Evidence from UK Company Accounts Data" Centre for Labour Economics, London School of Economics, Discussion Paper No. 353 (1989) where it is argued that "unlike the U.S. evidence, unions do not appear to reduce productivity growth in Britain. These results also do not suggest a significant explanatory role for union legislation because the "pro-union measures of the $1970 \mathrm{~s}$ do not seem to have had much effect". (See also Wadwani and Wall, "The Effects of Unions on Corporate Investment: Evidence from Accounts Data, 1972-86". Centre for Labour Economics, London School of Economics, Discussion Paper No. 354 (1989) where it is argued that "it is unlikely that industrial relations legislation has had any effect on investment"'.) Also important is Metcalf, "Water Notes Dry Up. The Impact of the Donovan Reform Proposals and Thatcherism at Work on Labour Productivity in British Manufacturing Industry" (1989) 27 British Joumal of Industrial Relations I; and Nolan, "Walking on Water? Pay, Productivity and British Manufacturing Performance Under the Conservatives"' (1989) 20 Industrial Relations Journal 121. 
since 1983, the increase has been mainly in the number of very vulnerable part-time staff employed in the service sector. Given the fact that the increase in part-time employment has been in jobs for less than 16 hours a week ${ }^{88}$ it is highly unlikely that labour law policy has had an impact in the creation of those jobs which have emerged. These people were already excluded from employment protection legislation, though in any event empirical evidence demonstrated clearly and unequivocally that this legislation did not affect an employer's decision to expand his or her labour force, serving only to induce more care in selection. ${ }^{89}$ Perhaps this reflects the reality that for workers the legislation failed to deliver all that it had promised..$^{90}$

The purported removal of obstacles from the labour market has thus not resolved the problem of labour costs or unemployment. There is on the contrary another problem on the horizon. For an economy carrying so many unemployed people it is paradoxical that there should now be major shortages of skilled labour. ${ }^{91}$ It is projected that by the mid-1990s the increased demand for labour is likely to outstrip supply. This reflects not only a failure of another thread of labour market policy - on education and training - it reflects also the counterproductive nature of the labour law contribution to that policy. It is now openly acknowledged that there is an increasing need to attract back into the labour market high-skilled married women. Yet as the MacDonald Commission appears to have acknowleged, rigid labour laws can discourage people from entering or returning to the labour market because of the denial of benefits to them. ${ }^{92}$ Indeed, evidence in Britain is beginning to show that as many as 6 million women are discouraged from entering the labour market because of discriminatory attitudes and conditions, the problems include sex bias leading to the segregation of women into a few occupations, low-paid junior occupations, and the lack of child care facilities. So while statutory employment standards did not, according to the empirical evidence, affect the demand for labour, according to the evidence its absence has a major impact on supply. The message may be getting through, for the government has abandoned proposals $^{93}$ to restrict employment protection rights to workers who are employed for twenty hours or more apparently on the ground that it would discourage women from returning to work.

\section{V.}

By way of conclusion, the Thatcher government can be seen to have introduced a major break with post-war economic policy. The central concern during

88. The evidence is summarised in Standing, Unemployment and Labour Market Flexibility, supra, note 7 at 61-63.

89. For an account of the weaknesses of this legislation, see Dickens, Dismissed (Basil Blackwell, 1985). The reality has now penetrated popular fiction. Witness the circumstances surrounding the dismissal of Danny Ram in David Lodge's Nice Work (Penguin, 1988).

90. See Wilkinson, "Government Policy and the Restructuring of Labour Markets", supra, note 8 at 23.

91. As reported in the Sunday Correspondent, 17 September 1989.

92. Royal Commission on the Economic Union and Development Prospects for Canada, supra, note 32 at $651-652$.

93. See Department of Employment. Building Business . . Not Barriers, supra, note 12. 
its tenure has been the control of inflation rather than the maintenance of full employment. Unemployment was to be dealt with by a new labour market policy which embraced a reduction of trade union power and the deregulation of statutory employment standards. This policy reflected a major break with the past in more ways than one, for the government was no longer concerned with constraining the arbitrary exercise of managerial power in the workplace or with encouraging individuals to participate in the process of making and administering the rules which govern their working lives. ${ }^{94}$ This rejection of fundamental precepts of liberal society - the rule of law and democratic self-government - is a high price to pay for economic efficiency which could only have been justified if the policy was as successful as the government claims. But the reality is that after ten years the British economy is extremely fragile. Unemployment is at an unacceptably high level and is almost certain to rise as interest rates (already at 14 per cent) push higher in response to a balance of trade deficit which this year is now likely to exceed $£ 21$ billion. It is a curious "success", of which one leading economist has written: "We are witness to something like a military disaster played in slow motion - some inglorious charge of the Light Brigade - and no amount of ceremony or swank can have the slightest effect on the outcome. It is simultaneously a great human tragedy and a gigantic cock-up." 95

94. These have been important features of the traditional policy which are generally overlooked by the new supply side people. For a particularly disappointing account, see Epstein "A Common Law for Labor Relations . . " supra, note 65. For a defence of this position, see Flanders, Management and Unions (Faber, 1975).

95. Godley, "Economic Disaster in Slow Motion", The Observer, 27 August 1989. 